\title{
The Correlation between Nicotine Dependence Level and Anxiety in Indonesian Adolescent Smokers
}

\author{
Yanuar Fahrizal, Nurvita Risdiana*, Febriliana Rustyawati \\ Department of Mental Health Nursing, School of Nursing, Universitas Muhammadiyah Yogyakarta, Yogyakarta, Indonesia
}

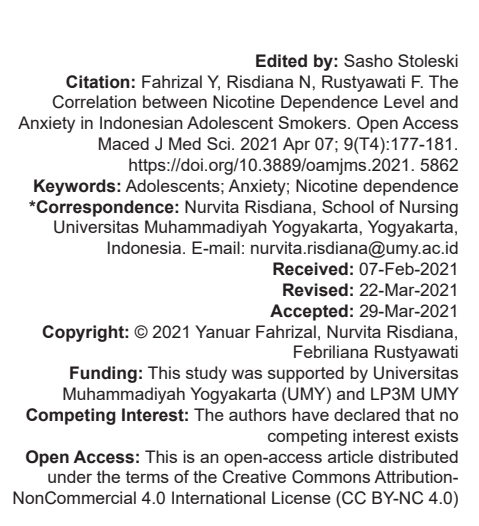

\begin{abstract}
BACKGROUND: Smoking behavior in Indonesia increases from year to year. The adverse effects of smoking do not appear directly after the cigarette use, but they will be seen in a few months or even in several years. The adverse effects of smoking include nicotine dependence, and anxiety disorder felt as a part of withdrawal symptoms.

AIM: This research aims to identify if there is a correlation between nicotine dependence level and anxiety level in adolescents.

METHODS: This study is non-experiment research with a quantitative method and a cross-sectional approach The sample of the study was 44 people. Fagerstrom Test for Nicotine Dependence was used as the instrument to measure the nicotine dependence level, while the instrument for anxiety level was carried out using the Taylor Manifest Anxiety Scale.

RESULTS: The correlation analysis between the level of nicotine dependence and anxiety conducted using Spearman rho non-parametric correlation analysis obtained a significant value of $0.0001(p>0.05)$. The value of $r=$ 0.979 showed a positive and robust correlation between nicotine dependence and anxiety level.

CONCLUSION: It is concluded that there is a strong and positive correlation between the nicotine dependence leve and the anxiety level in adolescents.
\end{abstract}

\section{Introduction}

Tobacco use among adolescents in Indonesia is $19.2 \%$ [1]. The adverse effects of smoking will be seen later in a few months or years. Some of the adverse effects of smoking are such as heart disease, cardiovascular, and stroke that are the leading cause of mortality in the world. The effects of smoking are felt not only physically but also mentally, such as anxiety. Tobacco use containing nicotine can increase the risk of anxiety disorder. Smokers experiencing anxiety will feel worse withdrawal symptoms when there is no nicotine level in the body. Nicotine withdrawal symptoms are experienced by most smokers when they try to quit smoking. The symptoms include mood disorder and affective disorder in the form of feelings of depression, worry, anxiety, irritability, fatigue, and drowsiness [2], [3].

The nicotine dependence level of smokers is closely related to nicotine withdrawal symptoms that will appear when there is no nicotine in the body. The nicotine withdrawal symptom becomes one of the reasons that make smokers find it hard to quit smoking. The smokers who successfully avoid smoking for 5 days have a higher possibility of quitting smoking because the nicotine withdrawal symptoms will be felt significantly in 3 days after quitting. However, it can happen continuously for weeks and will decrease after 14 days of quitting smoking [2], [3].

The high prevalence of smokers is shown in individuals with a general anxiety disorder. Smokers with anxiety disorder tend to smoke at a young age, and they will suffer from higher nicotine dependence that will cause worse withdrawal nicotine symptoms when there is no nicotine level in their body. Eventually, they will experience more difficulties in quitting smoking [2], [4], [5]. A higher prevalence of smokers is found in smokers with mental illness, including those who have anxiety disorder [6]. These people are considered to have a high risk of mortality related to diseases caused by smoking.

Weekly smokers (smoking 6-10 cigarettes in a week) and monthly smokers (smoking 0-1 cigarettes in a week) are reported that the weekly smokers have a higher level of nicotine dependence and withdrawal symptoms, more cigarettes to smoke, and higher depression than the monthly smokers [7]. The finding reveals the possibility of a high level of nicotine dependence having a high risk of withdrawal symptoms, including a high anxiety level.

Anxiety appears in minutes or hours when quitting smoking because there is no nicotine level in the body. The nicotine of cigarette smoke will be 
inhaled in the lungs and blood vessels, and later, it will go to the brain. When the nicotine from blood vessels gets to the brain, the nicotine will affect dopamine neurotransmitters, which regulate pleasant and calming feelings. If smokers quit smoking, the nicotine level in the body will decrease, causing withdrawal symptoms [8]. A mechanism that causes pleasing nicotine effect of mood and cognitive changes is called the neuromodulation mechanism of nicotine [9]. Quitting smoking, causing no nicotine level in the body, will lead to withdrawal symptoms such as anxiety that causes inconvenience.

This inconvenience can cause smoking recurrence of the smokers who initially quit smoking. If the anxiety level of smokers is identified, the withdrawal symptoms that appear can be controlled to help them quit smoking. It becomes a reason to identify the correlation between the nicotine dependence level and the anxiety level of smokers because anxiety is related to withdrawal symptoms that will appear. Thus, the anxiety level will be different in each nicotine dependence level of smokers. This study aims to determine the relationship between nicotine dependence and adolescent anxiety levels.

\section{Methods}

This study is a cross-sectional, nonexperimental quantitative research with a descriptive correlation analysis method to determine the correlation between nicotine dependence level and anxiety level. The population of the research was adolescent smokers in Bantul, one sub-district of Yogyakarta with an unknown total population. The total sample was 44 people selected using the Lemeshow formula with an unknown total population.

The sample was selected using purposive sampling that met the inclusion criteria as follows: Active adolescent smokers aged 17-25 years old and tobacco smokers who were willing to be the respondents. Meanwhile, the exclusion criteria were such as the adolescents suffering from an anxiety disorder, depression, dysphoria, electric smokers, and canceled their involvement as research respondents. This research was conducted from December 2018 to January 2019 after getting an ethical clearance license number 609/EP-FKIK-UMY/XII/2018. The instruments used in this research were the Fagerstrom Test for Nicotine Dependence and the Taylor Manifest Anxiety Scale to measure the level of nicotine dependence and anxiety. The nicotine dependence level was categorized as follows: $1-2$ is classified as very low, 3-4 is low, 5-7 is medium, and 8 is high. Meanwhile, the anxiety level is categorized as follows: $0-5$ is low, 6-15 is medium, and 16-38 is high. The data analysis used in this research was univariate and bivariate. Univariate analysis was used to show the frequency distribution and mean, while bivariate analysis used the Spearman rho non-parametric test to determine the correlation between the level of nicotine dependence and the level of anxiety.

\section{Results}

This research aims to display the data on nicotine dependence level and anxiety as well as finding out the correlation between nicotine dependence level and anxiety. Based on the characteristics of respondents, the respondents' age was between 19 and 24 years old, and they were male.

Meanwhile, the nicotine dependence level was categorized into low, medium, and high. Nearly all respondents had a very low nicotine dependence with a mean value of \pm SD $1.42 \pm 0.507$, with a total of 19 respondents (Table 1 ).

Table 1: Nicotine dependence in adolescent

\begin{tabular}{llll}
\hline Nicotine dependence & Mean \pm SD & Frequency $(\mathrm{f})$ & Percentage \\
\hline Very low & $1.42 \pm 0.507$ & 19 & 43 \\
Low & $3.47 \pm 0.514$ & 17 & 39 \\
Moderate & $5.75 \pm 0.886$ & 8 & 18 \\
High & 0 & 0 & 0 \\
Total & & 44 & 100 \\
\hline
\end{tabular}

The anxiety level of the adolescents was in a low category with a mean value of \pm SD $3.00 \pm 1.440$, with a total of 28 respondents (Table 2 ).

Table 2: Anxiety level in adolescent

\begin{tabular}{llll}
\hline Anxiety level & Mean \pm SD & Frequency $(\mathrm{f})$ & Percentage \\
\hline Low & $3.00 \pm 1.440$ & 28 & 64 \\
Moderate & $9.77 \pm 2.682$ & 13 & 29 \\
High & $19.67 \pm 3.215$ & 3 & 7 \\
Total & & 44 & 100 \\
\hline
\end{tabular}

The statistical test of Spearman rho showed $p=0.0001(p<0.05)$ and $r$-value of 0.979 , indicating a significant and strong correlation between the level of nicotine dependence and the level of anxiety (Table 3).

Table 3: Correlation between nicotine dependence and anxiety level in adolescent

\begin{tabular}{llll}
\hline Spearmen's Rho test & $\begin{array}{l}\text { Nicotine dependence } \\
(\text { Mean } \pm \text { SD) }\end{array}$ & $\begin{array}{l}\text { Anxiety } \\
\text { level (Mean } \pm S D)\end{array}$ & p-value \\
\hline $\begin{array}{l}\text { Correlation between nicotine } \\
\text { dependence and anxiety level }\end{array}$ & $3.00 \pm 1.71$ & $6.13 \pm 5.19$ & 0.00 \\
\hline
\end{tabular}

\section{Discussion}

The results of this study describe the correlation between the addiction level of nicotine and the anxiety level in adolescent smokers. Based on the respondents' age, the research result shows that the respondents' age is in the range of 19-24 years old (Table 4). Age 
profoundly influences the addiction level of nicotine and the success of quitting smoking. It is supported by the study stating that the younger the smoker' age is, the higher the addiction level on nicotine will be [10], [11]. It confirms that an individual will have a high possibility of success if he or she starts smoking after reaching the age of 20 years old.

Table 4. Respondence Characteristics

\begin{tabular}{llll}
\hline No & Characteristics & Frequency (f) & Percentage (\%) \\
\hline 1 & Age & & \\
& $19-24$ years old & 44 & 100 \\
2 & Gender & 44 & 100 \\
& Male & 44 & 100 \\
\hline
\end{tabular}

One of the withdrawal symptoms is anxiety, which is also found among teenagers. The most frequent psychological disturbance found among teenagers is anxiety $(65.2 \%)$, in which during this period, they are seeking for self-identity and considering that smoking is something making them seem mature, settled, and secure so that they can become a leader in a particular group. Smoking is also considered as an appeal for the opposite sex [12]. The reason adolescents smoke because adolescents often experience anxiety. This can increase the risk of nicotine dependence which will cause more severe withdrawal symptoms that can make it difficult for them to quit smoking in adolescents.

In addition to age, gender is also found to influence the addiction level. Based on gender, all adolescent smokers are males, with a total number of 44 respondents (Table 4). During the quitting smoking period, the males experience a withdrawal symptom that is lower anxiety compared to females [13]. Although the males are riskier in experiencing withdrawal symptoms like anxiety, they can control the anxiety symptoms better than females. Women are 2-3 times more likely to develop generalized anxiety disorder and panic disorder than men. This is because it is related to changes in the levels of the hormones progesterone and estrogen during life during the menstrual cycle so that it affects the severity of anxiety disorders in women [14].

The research results on 44 adolescent smokers show that the majority of respondents $(43.2 \%)$ were in the very low addiction level of nicotine (Table 1). Based on Table 1, it shows that the very low addiction level of nicotine is proven by the mean value of $\pm 1.42 \pm 0.507$, with the number of respondents of 19 people (43\%). Similar findings to this study show that adolescent smokers mostly have very low addiction level of nicotine $(58 \%)$ [15]. The very low addiction level of nicotine indicates that the nicotine binding with the brain and the nicotinic acetylcholine receptors(nAChRs) are still at a low level. Nicotine deriving from the cigarette smoke will be absorbed faster to the lung and diffused quickly to the brain tissues only in $7 \mathrm{~s}$. In the brain, nicotine will bind with the $n A C h R s$ receptor. The most $n A C h R s$ subunits in the human brain are $\alpha 4$ and $\beta 2$, having the most significant role in nicotine addiction [16]. The binding between nicotine and $\mathrm{nAChR}$ can stimulate the dopamine released by the mesolimbic, corpus striatum, and frontal cortex. Meanwhile, the release of dopamine will result in a happy feeling and can influence the reward system in the brain. One of the nicotine characteristics is that it can imitate the same reward system with its natural mechanism [8]. The binding nicotine level causes a low addiction level with the low nAChRs receptor. Therefore, the dopamine released is still at a low level causing the person to quit smoking and will have light and controllable withdrawal symptoms as the effects.

The very low addiction level of nicotine is also influenced by the amount of cigarettes consumed and the age when adolescents start smoking. In the very low addiction level of nicotine, adolescent smokers usually consume <10 cigarettes in a day [15], [17]. The smokers typically inhale the cigarette 10 times in 5 min and absorb 1 until $2 \mathrm{mg}$ of nicotine [18]. Besides the amount of daily consumed cigarette, the age when the smokers start smoking also influences the addiction level of nicotine. Among adolescent smokers, smokers beginning to smoke at an early age ( $<16$ years old) will have higher effects of high nicotine addiction in the future [11]. Adolescent smokers generally start smoking for the $1^{\text {st }}$ time at the age of $<15$ years old $(71.4 \%)$ [19]. Indonesia itself is entitled "Baby Smoker" as the prevalence of the number of smokers at an early age significantly increases each year.

The research results mostly show that the respondents have a low anxiety level (Table 3). The majority of adolescents experience low levels of anxiety [20]. Anxiety is a psychological disturbance that is frequently found among teenagers [21]. It explains that the anxiety will activate the sympathetic nerve, which is one of the autonomous nerve systems and will activate HPA axis (Hypothalamic-Pituitary-Adrenal axis) as the primary stress track which later stimulates the hypothalamus to release the corticotropin-releasing factor (CRF) hormone. After the hypothalamus releases $\mathrm{CRF}$, it will activate the pituitary gland releasing the adrenocorticotropic hormone (ACTH). ACTH will cause the adrenal gland positioning on the kidney organ that releases several hormones [22].

Several hormones will be released by the body when it feels anxious. The ACTH activating the adrenal gland will make it release several hormones. The adrenal glands are made up of two parts, the adrenal cortex and the adrenal medulla, each of which releases hormones simultaneously when the body feels anxiety. The adrenal cortex will release cortisol hormone, which causes common adaptation syndrome as an adaptation mechanism toward anxiety, and medulla adrenal will release the adrenaline hormone (epinephrine), causing the body to be in fight or flight response condition [22], [23], [24]. Besides the physiological anxiety mechanism, anxiety level can also be influenced by gender and an individual's coping mechanism in overcoming anxiety.

The female gender is more anxiety prone. Thus, males experience a lower anxiety level 
compared to females [12], [25]. The statement is in line with this study strengthening that low anxiety level on males is shown in Table 2. The low anxiety level can also be influenced by the coping mechanism, which is in line with the study that found that the adolescents have an adaptive coping mechanism (70.6\%) and various coping strategies based on the stress level experienced by the individuals. The more adaptive the individual's coping mechanism in overcoming stressor is, the lower the anxiety level experienced by the individuals will be, and vice versa. There are some common mechanisms that can be used for decreasing low anxiety, such as crying, sleeping, eating, yawning, laughing, cursing, doing physical exercises, and daydreaming [23].

The results of the analysis conducted in this study mentioned in Table 3 show that there is a correlation between the addiction level of nicotine and the anxiety level among adolescents. The correlation coefficient $(r)$ (Table 3 ) shows a perfect correlation having a positive correlational direction, which indicates that the higher the addiction level of nicotine is, the higher the anxiety level will be. Adolescent smokers mostly have low addiction level [15]. The before-mentioned study is in line with this study's results showing that most adolescent smokers have a low addiction level of nicotine. It is because the nicotine exposure binding with the $\mathrm{nAChRs}$ receptor is still at a low level; thus, the released dopamine is still at a low level, and the withdrawal symptoms felt can still be compensated by the body.

The withdrawal symptoms as the impact of quitting smoking occur as there is no nicotine level inside the body. It will make the CRF hormone released by the hypothalamus that will activate the pituitary gland. This gland releases ACTH having impacts on the release of cortisol and adrenalin (epinephrine) hormone as the adaptation mechanism of the body. As a result, it will activate the fight or flight responses as the body respond to anxiety occurring from the withdrawal symptoms [21].

\section{Conclusion}

The smokers will experience withdrawal when they quit smoking so that it causes symptoms like anxiety due to nicotine. In this study, it proves that there is a correlation between the addiction level of nicotine and the anxiety among teenagers. Therefore, one of the reasons hampering the smokers to quit smoking is the withdrawal including anxiety. Based on the results, an appropriate method on how to handle anxiety in the program of quitting smoking. Thus, it is expected that the smokers who are trying to quit smoking can successfully pass through the withdrawal phase.

\section{References}

1. Ministry of Health Republic of Indonesia, World Health Organization and CDC. Global Youth Tobacco Surver Lembar Informasi Indonesia 2019. Geneva: World Health Organization; 2020. Available from: https://www.who.int/docs/default-source/ searo/indonesia/indonesia-gyts-2019-factsheet-(ages-13-15)(final)-indonesian-final.pdf?sfvrsn=b99e597b_2.

2. Caponnetto P, Polosa R. Common predictors of smoking cessation in clinical practice. Respir Med. 2008;102(8):1182-92. https://doi.org/10.1016/j.rmed.2008.02.017

PMid:18586479

3. Hesami Z, Alvanpour A, Kashani BS, Tafti SF, Heydari GR. Severity of nicotine withdrawal symptoms after smoking cessation. Tanaffos. 2010;9(1):42-7.

4. Fluharty M, Taylor AE, Grabski M, Munafò MR. The association of cigarette smoking with depression and anxiety: A systematic review. Nicotine Tob Res. 2017;19(1):3-13. https://doi. org/10.1093/ntr/ntw140 PMid:27199385

5. Moylan S, Jacka FN, Pasco JA, Berk M. Cigarette smoking, nicotine dependence and anxiety disorders: A systematic review of population-based, epidemiological studies. BMC Med. 2012;10(1):123. https://doi.org/10.1186/1741-7015-10-123 PMid:23083451

6. Lasser K, Boyd JW, Woolhandler S, Himmelstein DU, McCormick D, Bor DH. Smoking and mental illness: A population-based prevalence study. J Am Med Assoc. 2000;284(20):2606-10. https://doi.org/10.1001/jama.284.20.2606 PMid: 11086367

7. Panday S, Reddy SP, Ruiter RA, Bergström E, de Vries H. Nicotine dependence and withdrawal symptoms among occasional smokers. J Adolesc Health. 2007;40(2):144-50. https://doi.org/10.1016/j.jadohealth.2006.09.001 PMid:17259054

8. Benowitz NL. Nicotine addiction. N Engl J Med 2010;362(24):2295-303.

PMid:20554984

9. Rai IB, Artana IG. Merokok dan ketergantungan nikotin pada penduduk tenganan pegringsingan, Karangasem, Bali. J Respirol Indones. 2009;29(4):1-7.

10. National Institute of Drug Abuse. Drugs, Brains, and Behavior: The Science of Addiction. Bethesda: National Institute of Drug Abuse; 2014

11. Charkazi A, Sharifirad G, Zafarzadeh A, Shahnazi H. Age at smoking onset, nicotine dependence and their association with smoking temptation among smokers. Bull Environ Pharmacol Life Sci. 2016;5(5):8-13.

12. Masdar H, Saputri PA, Rosdiana D, Chandra F, Darmawi D. Depresi, ansietas dan stres serta hubungannya dengan obesitas pada remaja. J Gizi Klin Indones. 2016;12(4):138. https://doi.org/10.22146/ijcn.23021

13. Torres O V., O'Dell LE. Stress is a principal factor that promotes tobacco use in females. Prog Neuropsychopharmacol Biol Psychiatry. 2016;4(65):260-8. https://doi.org/10.1016/j. pnpbp.2015.04.005 PMid:25912856

14. Jalnapurkar I, Allen M, Pigott T. Sex differences in anxiety disorders: A review. J Psychiatry Depress Anxiety. 2018;4(1):1-9.

15. Lamin RA, Othman N, Othman CN. Effect of smoking behavior on nicotine dependence level among adolescents. Procedia Soc Behav Sci. 2014;153:189-98. https://doi.org/10.1016/j. sbspro.2014.10.053

16. Prochaska JJ, Benowitz NL. The past, present, and future of 
nicotine addiction therapy. Annu Rev Med. 2016;67(1):467-86. https://doi.org/10.1146/annurev-med-111314-033712

PMid:26332005

17. Donny EC, Griffin KM, Shiffman S, Sayette MA. The relationship between cigarette use, nicotine dependence, and craving in laboratory volunteers. Nicotine Tob Res. 2008;10(3):447-55. https://doi.org/10.1080/14622200801901906

PMid: 18569770

18. Siqueira LM. Nicotine and tobacco as substances of abuse in children and adolescents. Pediatrics. 2017;139(1):e20163436. https://doi.org/10.1542/peds.2016-3436

PMid:27994114

19. Tristanti I. Adolescents and Smoking Behavior. Yogyakarta: The $3^{\text {rd }}$ University Research Colloquium; 2016. p. 328-42.

20. Alamsyah A, Nopianto. Determinan perilaku merokok pada remaja. J Endur. 2017;2(1):25-30. https://doi.org/10.22216/jen. v2i1.1372
21. Stephens MA, Wand G. Stress and the HPA axis: Role of glucocorticoids in alcohol dependence. Alcohol Res. 2012;34(4):468-83.

PMid:23584113

22. Sugiharto. Fisioneurohormonal Pada Stresor Olahraga. J Sains Psikol. 2012;2(2):54-66.

23. Stuart GW. Principles and Practices of Psychiatric Nursing. $10^{\text {th }}$ ed. China: Elsevier Mosby; 2013. p. 28-9.

24. Pramana KD, Okatiranti $O$, Ningrum TP. The Relationship between Anxiety Level and the Incidence of Hypertension in Tresna Werdha Senjaeawi Social Home, Bandung. J Nursing Science. 2016;4(2):116-28. https://doi.org/10.33024/hjk.v5i1.856

25. Besson M, Forget B. Cognitive dysfunction, affective states, and vulnerability to nicotine addiction: A multifactorial perspective. Front Psychiatry. 2016;7:1-24. https://doi.org/10.3389/ fpsyt.2016.00160

PMid:27708591 